\title{
Destination Management of Religious Tourism in Cirebon Indonesia
}

\author{
Tanti Kustiari \\ Pascasarjana Agribisnis at Polije, Indonesia \\ tantikustiari@gmail.com
}

\author{
M. Taufik H \\ Syarif Hidayatullah State Islamic University, Indonesia \\ taufik.mtht@yahoo.co.id
}

\begin{abstract}
Since a long time ago, most of mosque role has been merely for worship, mosques in Cirebon are included. Now, as time flies, the function of mosque in the area has transformed to be religious tourist resorts. The program has an impact on improving the socio-economic environment of the community. The quality of religious tourist resort management is determined by the quality of mosque management resources as tourist destinations in Cirebon. The study was conducted in Cirebon religious tourist destination in 2016. The research respondents were twenty mosque managers from seven tourist mosques. The research aims to identify and analyze: (1) the characteristics of religious tourist destination in Cirebon; (2) the characteristics of human resource competence in managing the attractiveness of religious tourist destinations of Cirebon; and (3) the implications of management resource gap in managing Cirebon religious tourist destinations. Cirebon is expected to be widely known as religious tourist icon that has a complete appeal of cultural traditions, socio-economic religious, historical activities. The research deployed a quantitative method and supported by relevant literature review. The results showed: (1) religious tourist destinations in Cirebon has uniqueness with a large number of customers. However, existing tourism activities have not been expanded; (2) competent religious tourist management resources can be improved through active learning, achievement driven, and ability to cooperate; and (3) strengthening the role of education and training.
\end{abstract}

Keywords: management, destination, tourism, religion

\section{INTRODUCTION}

Cirebon has a potential religious tourist destinations, culture and history. This comes true as Cirebon has a distinctive palace in the form of Kasepuhan Sultanate, Kanoman and Kacirebonan. The three palaces are still keeping the tradition of long ritual activities of the Talisman [2]. Foreign tourists and domestic tourists are quite enthusiastic with religious tourist areas in Cirebon. Foreign tourists are visitors of a place with no purpose to earn an income during the visit. There are two types of travelers based on time limits ie tourists with 12 months visiting time, and travelers with less than 24 hour time visit (www.cirebonkota.bps.go.id, 2017).

According to the Head Disporbudpar (The Department of Culture and Tourism), the number of tourists in Cirebon in 2013 were around 417,000 about $23 \%$ of tourist number in the previous year. Overall, local tourists visit for religious tourist destinations or pilgrimage, while others come to Cirebon to transit from long journey [3]. Now, visiting tourists aim not only for religious travel but also for transit. Travelers choose to transit in religious tourit areas. They take a break in the sights while enjoying the beauty of the architects and see the uniqueness of the mosque in Cirebon. The travelers take advantage of the mosque's tourism function as the most comfortable place to rest, worship, buy, and cleanse [1].

After the roads along the Pantura are well built, the journey from the capital city of Jakarta becomes unhandicaped and quickly toward the cities of Central Java and East Java. One of the religious tourist destinations is the city of Cirebon as it is located very strategically between West Java and Central Java. Cirebon was chosen as a stopover from a long trip while traveling on a religious trip. Moreover, Cirebon is well-known as administrative region with almost perfect tourism programs, especially religious tourist resorts. According to Junaid (2015), the characteristics of tourist destinations are owning tourism products offered, having integrated services which involve individual, community and private / government agencies. Thus, based on these characteristics, Cirebon includes the religious tourist destinations, with its superiority in the form of mosques.

Based on the research results of Hermansyah and Hidayatullah (2016), religious tourist resorts in Cirebon are in the form of mosques about seven mosques such as Panjunan, Cipta Rasa, At Taqwa, Kanoman, Astana Gunung Jati, Megu Gede and Agung Sumber. The seven mosques are unique in the form of architecture such as palace, heirlooms, wells and tombs, for instance: cultural traditions such as Grebeg Maulid, Muharaman, Pajang Jimat, Hadroh [4]. Meanwhile, according to research Tunggadewi (2013) mosque component in the tourist destination of Central Java greatly affect the arrival of tourists, such as Asmaul Husna tower components, Eelectric Umbrella, gate, building function, mosque roof, mosque roof minaret, plaza, thermal comfort, visual, spatial.

The attractiveness of the mosque as religious tourists resorts are not only from the side of cultural tradition but also because of the uniqueness of architecture and comfort of the mosque. Tourists visit not only for reasons of worship, but also for reasons: (1) something to see; (2) something to do; and (3) something to buy (Manurung, 2014). Based on the interview results with the mosque officials in seven religious tourism destinations Cirebon known that the management of tourist mosques in Cirebon including medium category (Hermansyah and Hidayatullah, 2016). This is because the management of infrastructure facilities owned by the mosque is less than optimal. In fact, the board realizes that the mosque's infrastructure facilities are part of religious tourism that attracted many tourists.

The inability to properly manage religious tourism is a testament to the low ability to take advantage of the growing number of tourists to destinations in Cirebon. This study will explain the phenomenon of religious tourism and its implications for the development of management resources in 
religious tourism management. Religious tourism based on the mosque in Cirebon area is expected to be a key change for the socio-economic and cultural environment in the future. To that end, preserving and developing the physical uniqueness of mosques and traditions of religious values and cultural diversity as a religious tourism worth visiting and known to the public widely feasible to do immediately. Through religious tourism, administrators can be intercultural, intercultural liaison.

The purpose of the research is to describe and analyze: (1) characteristics of religious tourism destinations in Cirebon; (2) describes the characteristics of human resource capacity in managing the attractiveness of religious tourism destinations in Cirebon; and (3) religious tourism management needs to be integrated with the managerial capability of religious tourism manager and provision of facilities.

\section{METHODS}

The research uses quantitative descriptive approach supported by qualitative study to explain the characteristics of religious tourism destinations in Cirebon and explain the ability of human resources in managing religious tourism resources. The study is complemented by literature review to analyze and clarify phenomena. Next synthesis to explain the management of religious tourism oriented to the convenience of tourists. The research was conducted at 7 mosques as destination of religious tourism in Cirebon in September 2016. The location of the research is determined purposively at the location of religious tourism destination in Cirebon Regency, Central Java Province, Indonesia. Research respondents are mosque administrators in 7 religious tourism destinations of 20 people in Cirebon. Each religious tourism destination is represented by 3 or 2 people. The data and information were collected through interviews and in-depth observation.

\section{RESULT AND DISCUSSION}

Among the several mosque-based religious tourism destinations are unique to each mosque that attracts local and foreign tourists, both tourists who are just recreational and tourists who come to recognize and learn about religion, culture, and local traditions. The tourists have various purposes in doing religious tours. Along with the development of transportation facilities such as the construction of Cipali toll road connecting the city of Jakarta with the city of Cirebon, the city of Cirebon is very strategic to become a multi-purpose tourist destination. Tourist destination in Cirebon are strategic as transit destination from long trips also become the city of choice as a religious tourist destination. The number of tourists in Cirebon has the potential to increase steadily. However, if the potential increase in the number of tours is not matched by the management of mosque tourism resources, better religious promotion then religious tourism destinations in Cirebon mosques cannot compete with religious tours from various destinations.

Thus, the study of the characteristics of mosque-based religious tourism resources in Cirebon as well as the level of human resource capacity in the management of religious tourism attraction becomes important. The objective is to develop human resource capability in managing religious tourism that is sustainable and competitive. Therefore, the characteristics of mosques as a religious tourist destination in Cirebon, Central Java, Indonesia will be intensively studied. Some religious tourist characteristics focus on the discussion of educational, social and economic activities, as well as the characteristics and characteristics of visitors. Furthermore, the level of ability of managers in managing religious tourism is also studied in order to determine its development strategy. The Characteristic of Mosque-based Religious Tourist Destination in Cirebon:

\section{Mosque Programs as Religious Tourist Destination} in Cirebon

The mosque is known as the cultural heritage of society because the mosque runs the role of preservation of cultural customs, religious values, protecting historical objects such as pulpit, drum, spear. The results showed that several religious tourism destinations have various educational, socio-economic activities. These activities are part of the effort to market the icon of Cirebon as a religious tourism worthy of being recognized and visited. Details can be seen in Table 1.

Table 1

Programs of Social Economic Eduaction of Mosque-base Religious Tourism Destination in Cirebon

\begin{tabular}{|c|c|c|c|}
\hline $\begin{array}{c}\begin{array}{c}\text { Mosque-base Religious Tourist } \\
\text { Destination }\end{array} \\
\end{array}$ & Education & Social & Economy \\
\hline Astana Gunung Jati Mosque & Quranic Educational Institution, Quran Recital & Sacrificied animal distribution & No information \\
\hline Agung Cipta Rasa Mosque & Quranic Educational Institution, Quran Recital & $\begin{array}{l}\text { Aid for orphans, ambulance, } \\
\text { Sacrificed animal distribution }\end{array}$ & No information \\
\hline Kramat Megu Mosque & Islamic School, Quran Recital & $\begin{array}{l}\text { Aid for orphans, Sacrificed animal } \\
\text { distribution }\end{array}$ & No information \\
\hline Raya At Taqwa Mosque & $\begin{array}{l}\text { Language course, house of Tahfidz, Dawn } \\
\text { Lecture, Radio for dakwah, Lecture by Habaib }\end{array}$ & $\begin{array}{l}\text { Lazisa, ambulance, Scholarship, } \\
\text { Moque coaching }\end{array}$ & $\begin{array}{l}\text { Cooperation, } \\
\text { Business centre }\end{array}$ \\
\hline Keraton Kanoman Mosque & Quranic Educational Institution & No information & No information \\
\hline Agung Sumber Mosque & Quranic Educational Institution & Sacrificied animal distribution & No information \\
\hline Karomah Depok Mosque & Tabligh Akbar, Recital & No information & No information \\
\hline
\end{tabular}

Most religious tourism mosques focus on non-formal religious and social education activities. Since time immemorial, the activities have been stagnant and there has been no significant change. What needs to be expanded is the development of non-religious roles such as language courses, health, 
community economic development. The diversity of activities and expansion of At Taqwa Mosque's role in economic empowerment and environmental awareness can serve as an example of increasing religious tourism branding in Cirebon. In marketing religious tourism mosque must have a creative, innovative program as a religious tourism attraction worth a visit.

\section{Tourists of Religious Tourism}

Indonesian people love religious travel in the city of Cirebon. They came to know the physical uniqueness of the mosque, as well as familiar with cultural traditions preserved by mosques such as Grebeg Maulid events, Pajang Jimat (displaying amulets), Muharaman, Hadroh and many others. The research result shows a large number of tourists to religious tourist resorts. This can be identified through types of tourists who visit.
The nature of tourists who visit diverse as a traveler and some are staying. The duration of the visitor visit time is less than 24 hours, while others with more than 24 hours stay. Tourists from different types of angle that comes in large groups with buses, and there is also a small group with a car or two-wheeled vehicles. The number of tourists driving buses as many as 50 people, while small groups amounted to approximately 15 people. Details can be seen in the table below.

Total of seven mosques are a tourist destination of religious tourists. Every month the mosque is the arrival of a group of visitors about 100 to 3 buses. The highest tourist destination tourist destination is the Astana Gunung Jati mosque. Every month, the mosques serve around 100 buses of visitors on average. Then the next tourist destination Grand Cipta Rasa mosque serves about 60 buses of visitors every month on average.

Table 2

\begin{tabular}{lccl}
\multicolumn{1}{c}{ Types of Tourists in Cirebon Religious Tourism Destinations } \\
\hline \multicolumn{1}{c}{ Tourists } & Total & \multicolumn{2}{c}{ Remarks } \\
\hline $\begin{array}{l}\text { Time of Visit } \\
\text { Travel (less than 24 hours) }\end{array}$ & 4 & Moques & $\begin{array}{l}\text { : Astana gunung jati, Keraton Kanoman, } \\
\text { Agung sumber, Kramat Megu. }\end{array}$ \\
$\begin{array}{l}\text { Stay (24 hours or more) } \\
\text { Group of Tourist }\end{array}$ & 3 & Moques & $\begin{array}{l}\text { : Cipta Rasa, At Taqwa, Karomah } \\
\text { Small group }\end{array}$ \\
$\begin{array}{l}\text { Big group } \\
\text { Source: Adapted Primary Data (2016) }\end{array}$ & 1 & Mosques & $: \begin{array}{l}\text { Kramat Megu. } \\
\text { Astana gunung jati, Cipta Rasa, At Taqwa, } \\
\text { Keraton Kanoman, Agung sumber, karomah }\end{array}$ \\
\hline
\end{tabular}

\section{The Characteristic of Destination Appeals Management of Religious Tourist Resorts in Cirebon}

Cirebon is well-known as the city of guardians (Hariyanto, 2016). Cirebon became the religious tourist destination of the most popular visitors along with high religious needs in the community. Culture, Religion and History is a leading tourist attraction in Cirebon that has provided various effects on other resources. The existence and sustainability of religious tourism depends on the seriousness of the manager in managing attractiveness or excellence.

Table 3

Mosque-based Appeal Management in Cirebon Destinations

\begin{tabular}{|c|c|c|c|c|c|}
\hline \multirow[b]{2}{*}{$\begin{array}{c}\text { Mosque-base Religious Tourist } \\
\text { Destination }\end{array}$} & \multicolumn{5}{|c|}{ Tourist Resort Appeal Management } \\
\hline & $\begin{array}{l}\text { Mosque } \\
\text { Manuals }\end{array}$ & $\begin{array}{c}\text { Information } \\
\text { Center }\end{array}$ & $\begin{array}{c}\text { Physical \& } \\
\text { non-physical } \\
\text { uni-queness }\end{array}$ & $\begin{array}{l}\text { Performance / } \\
\text { Demonstration }\end{array}$ & $\begin{array}{l}\text { Mosque } \\
\text { Variety }\end{array}$ \\
\hline Astana Gunung Jati Mosque & - & $\sqrt{ }$ & $\sqrt{ }$ & - & 2 \\
\hline Agung Cipta Rasa Mosque & - & - & $\sqrt{ }$ & - & 4 \\
\hline Kramat Megu Mosque & - & - & $\sqrt{ }$ & - & 2 \\
\hline Raya At Taqwa Mosque & $\sqrt{ }$ & $\sqrt{ }$ & $\sqrt{ }$ & - & 0 \\
\hline Keraton Kanoman Mosque & - & - & $\sqrt{ }$ & $\sqrt{ }$ & 2 \\
\hline Agung Sumber Mosque & $\sqrt{ }$ & $\sqrt{ }$ & $\sqrt{ }$ & - & 0 \\
\hline Karomah Depok Mosque & $\sqrt{ }$ & $\sqrt{ }$ & $\sqrt{ }$ & - & 1 \\
\hline $\begin{array}{c}\text { Total } \\
\end{array}$ & 3 & 3 & 7 & 1 & 13 \\
\hline
\end{tabular}

Source : Adapted Primary Data (2016)

Notes $: \sqrt{ }=$ Available

Based on Table 3, shows the mosque has not been well managed. Potential physical uniqueness and nonphysical mosque has not been marketed to the fullest. The board has not been able to use various media to inform and promote widely to the public. Mosques that have uniqueness of architecture, heirlooms such as pulpits, spears tend to be less promotion of religious attractions, while the mosque that promotes religious tourism, but not quite supported by the attraction of the diversity of the mosque zones.
One of the illustrations, the Grand Mosque of Cipta Rasa has the uniqueness as a grand mosque with the oldest building in the center of the city is a religious tourism attraction and is supported by the diversity of 4 zones ie the area of the palace, springs, heirlooms and funeral areas. What is owned by Cipta Rasa Great Mosque is not done publication. Management assumes no religious tourism promotion, many people who come to see the uniqueness of religious tourism Great Mosque Cipta Rasa. 
Implementation of Community Empowerment Activities as Tourism Attractions

One of the attractions of religious tourism is the ability to display services and meet the needs of tourists. Fulfillment of religious tourist comfort cannot be done by unilateral administrators, but the religious tour operators need to involve other parties such as community, government, private. With the hope of mosque-based religious tourism can give a positive multi-effect for the surrounding environment.

Table 4

People Empowerment Programs of Mosque-based Religious Tourism Destinations in Cirebon

\begin{tabular}{|c|c|c|c|c|}
\hline \multirow{2}{*}{$\begin{array}{l}\text { Mosque-based Religious } \\
\text { Tourism Destinations }\end{array}$} & \multicolumn{4}{|c|}{ People Empowerment Program } \\
\hline & $\begin{array}{c}\text { In cooperation with } \\
\text { tourism agents }\end{array}$ & $\begin{array}{l}\text { Resaurants / warungs / } \\
\text { catering supplier }\end{array}$ & $\begin{array}{l}\text { Souvenir } \\
\text { shops }\end{array}$ & Homestay \\
\hline Astana Gunung Jati & - & $\sqrt{ }$ & $\sqrt{ }$ & $\sqrt{ }$ \\
\hline Agung Cipta Rasa mosque & - & $\sqrt{ }$ & $\sqrt{ }$ & - \\
\hline Kramat Megu mosque & - & - & - & - \\
\hline Raya At Taqwa mosque & - & $\sqrt{ }$ & $\sqrt{ }$ & - \\
\hline Keraton Kanoman mosque & - & - & - & - \\
\hline Agung Sumber mosque & - & $\sqrt{ }$ & $\sqrt{ }$ & - \\
\hline Karomah Depok mosque & - & - & - & - \\
\hline $\begin{array}{c}\text { Total } \\
\end{array}$ & $\mathbf{0}$ & 4 & 4 & 1 \\
\hline
\end{tabular}

The traders around mosques of religious tourism destinations play a pivotal role in supplying tourists'various needs. According to Table 4, most of mosques in cooperated in religious tourism destinations involved people as business partners. The people provide meals, various souvenirs, inns which are parts of important needs for tourists as most mosque managements cannot provide homestay. As a matter of fact, more traders should be encoureged to provide more religious tourism packages such as transportation among religious tourism mosques in Cirebon.

Promotional Programs of Religious Tourist Appeal

Promotional programs play a pivotal role in endorsing religious tourism attraction. The programs consists of some promotional activoties such as art calendar creation, advertisment, and branding on religious tourism uniqueness. Overall, religious tourism destination in Cirebon carry out direct as well as indirect promotion. In terms of direct promotion, religious tourism board of management become the initiator of some events such as seminar, meetings, Quran recital, etc while the indiret promotion was conducted through mass media and art calendar.

Mass media (newspaper) promotes the uniquenes of religious tourism attraction. The ideas promoted through newspaper come from people specifically pay attention to religious tourism. According to types of promotional programs, religious tourism board of managers have not made the most use of mass media and internet availability.

Table 5

Promotional Programs of Religious Tourist Destinations in Cirebon

\begin{tabular}{lcccc}
\hline \multirow{2}{*}{$\begin{array}{c}\text { Mosque-based Religious } \\
\text { Tourism Destinations }\end{array}$} & \multicolumn{4}{c}{ Promotional Programs of Religious Tourism } \\
\cline { 2 - 5 } & Sponsor/promotor & Calender of art & $\begin{array}{c}\text { Branding of } \\
\text { mosque uniqueness }\end{array}$ & Advertisement \\
\hline Astana Gunung Jati & $\sqrt{ }$ & $\sqrt{ }$ & $\sqrt{ }$ & $\sqrt{ }$ \\
Agung Cipta Rasa mosque & $\sqrt{ }$ & $\sqrt{ }$ & - & - \\
Kramat Megu mosque & $\sqrt{ }$ & $\sqrt{ }$ & - \\
Raya At Taqwa mosque & $\sqrt{ }$ & - & - & - \\
Keraton Kanoman mosque & - & $\sqrt{ }$ & - \\
Agung Sumber mosque & $\sqrt{c}$ & - & - & - \\
Karomah Depok mosque & $\mathbf{1}$ & $\mathbf{4}$ & $\mathbf{4}$ & $\mathbf{1}$ \\
\hline \multicolumn{1}{c}{ Total } & $\mathbf{6}$ & & & \\
\hline
\end{tabular}

Source : Adapted Primary Data 2016

Note $: \sqrt{ }=$ Available

The Implication and Human Resources Development of Religious Tourism Destinations in Cirebon

The uniqueness and strong points of religious tourism destinations in Cirebon vary. To be iconic, most mosques should be able to learn from other religious tourism destinations to develop their uniqueness. the development of religious tourism can succeed through some features: (1) the development of human resources competence in managing tourist resorts; and (2) in providing a wide range of facilities for religious tourism. The development of competent through acteive learning process, encouragment for achievement, and the competence of cooperation (Hermansyah and
Hidayatullah, 2014). Religious tourism can provide customers with service and perfectness in integrated cooperation with various agents of different aspects.

Furthermore, active learning on opening new events, internet use, providing tourist guide in terms of promotional programs need to be immediately conducted as well. The importance of tourism manual provision is due to female tourists indicating high level of preference for female role interpreatation between Islam and Arabian roles (I-Ling, Kuo, 2007). According to a research by Astuti (2010) tourism promotion can be carried out through mingling promotions such as: (1) advertisement through leaflet and booklet to tourist and prospective tourits, publication by mas and electronic 
medias; (2) Promotional sales through regional, national and international exhibition; (3) human relationship concerns cooperation with people, private and state institution / organisation; (4) direct promotion for tourist resorts to tourists on visits; and (5) promotional marketing can also be carried out through website creation on tourism.

Moreover, the human resources of management boards must also be encouraged to broaden their horizons of religious tourism suchas knowledge of history, traditions,cultures, religions in order to able to educate, to inform and also to reply questions from tourists. Tourism board of management also need to learn independently to develop their knowledge and horizon of culture rituals such as Pajang Jimat, Grebeg Maulid, Muharaman and update of contemporer news [3] suggested that host should be able to bridge the gap with visitors through the information of religion, habits and ways of life of the people nearby the mosque. The management board can be the liaison among cultures.

Thus, the competence of cooperation with other agents such as community and institutions needs to be possesed as all agents are needed to involve in any event. The better and more various programs conducted by religious tourist resorts, the more tourists will likely visit the destination. The mangement boards can also provide any facilities on demands. As a matter of fact, tourists need easy access to any tourist resorts that management board can put the two agents in a prospective meetings through some programs such as art shop with affordable items. In addition, handcraft inventor and traders need to be involved to supply various goods needed with proper shops. Similarly, the need for homestays can also be fulfilled with cooperation between community and homestay suppliers so that religious tourism organisers can toruists with insightful information of homestays.

Learning center for recreation can also be provided through cooperation between board of management and educational institutions. Tour organizers play a pivotal role as providers for students visit program so that they can learn about the reservation of culture, tradition and history. Types of touris vary with various facilities. According to Sapri, et al., [5] good mosque management is through good facility provision for good programs.

According to research by Yulianie (2015) the success of tourism development depends on board of organizers who can develop tourist resort in the community. People will be empowered through educations, trainings, and coaching and assistance for accomodations, responsibility to maintain the potential of tourist resorts. The development program attraction is conducted by renovating slum areas to be clean, comfortable and well-managed areas. The relocation of parking area, information center, toilets, walking tracks for pedestrian, rest area, two gate ways, and artshop.

Religious tourism management can be carried out through well-qualified facilities. This is particularly true with Sapri [5] adopting Yulianie (2015) that developing religious tourism should be begun with cleanliness, comfort, and adequate facilitiy and accommodation. The development religious tourism deals with service improvement and facilities completeness. With the touch of modern management the attraction of religious tourism destinations will eventually improve the good image of Cirebon as iconic tourist resort in Central Java.

\section{CONCLUSION}

Religious tourism destinations in Cirebon has uniqueness especially in traditions, culture, history and architechtures. Therefore, the number of visiting tourist keeps growing. However, the uniqueness is not specifically supported by various tourism programs provision. In addition, the competence of religious tourism resources is not supported by proper management. The competent management of religious tourism resources can be improved through active learning process, encouragment for achievement, and the abilty to cooperate with a wide range of agents. The management of religious tourism can be integratedly facilitited by the development of managerial competence of religious tourism organizers and the provision of adequate, qualified, well-managed facilities.

\section{REFERENCES}

[1] Astuti, W. A. 2010. Aktivitas Komunikasi Pemasaran Objek Wisata Masjid Agung Demak dan Makam Kadilangu. Retrieved December 20, 2016, from https://digilib.uns.ac.id/dokumen/abstrak/11461/aktivit as-komunikasi-pemasaran-objek-wisata-masjid-agungdemak-dan-makam-kadilangu.

[2] Hariyanto, I. B. 2016. Destinasi Wisata Budaya dan Religi di Cirebon. Ecodemica, 4(2), 23-32.

[3] I-Ling, K. 2007. Where West Meets the Middle East Jumeirah Mosque Visit. Journal of Tourism Recreation Research, 32(15), 1-9.

[4] Manurung, E. T. 2014. Perbandingan Kontribusi Industri Pariwisata dalam Meningkatkan Pendapatan Asli Daerah di Kabupaten Bandung dan Jember. Research Report. Bandung: University of Katolik Parahyangan.

[5] Sapri, M., Zafirah, A. M., Ibrahim, S., Anthoni, A. T., Farahwahida, M. Y., Rosadah, M., and Mustafa, O. 2014. Potential of Facilities Management in Lifting Mosque Management Function. International Conference on Mosque, Zakat, and Waqaf (i-MAF), December 1-2. 